\title{
Women's Military Uniform During the Second World War: How Women Maintained Their Femininity
}

\author{
Miku Hirata \\ Graduate School of Human Sciences and Design, Japan Women's University, Tokyo, Japan \\ Email address: \\ mikuhirata70@gmail.com \\ To cite this article: \\ Miku Hirata. Women's Military Uniform During the Second World War: How Women Maintained Their Femininity. American Journal of Art \\ and Design. Vol. 6, No. 1, 2021, pp. 26-37. doi: 10.11648/j.ajad.20210601.14
}

Received: March 13, 2021; Accepted: April 1, 2021; Published: April 12, 2021

\begin{abstract}
The study explores how women in military uniforms maintained their femininity during the Second World War. It considers the uniforms that women belonging to the Women's Royal Naval Service (WRNS), the Auxiliary Territorial Service (ATS), and the Women's Auxiliary Air Force (WAAC) wore. Previous research on women's military uniforms during the war has been done from above: why the authority did not allow women to wear trousers and how the government tried to control their uniform. It is necessary to explore women's military uniform from below as well as from above: how women themselves think of their uniforms, what feelings and mentalities to their uniforms they had and how women in military uniform tried to retain their femininity even in the war. This study mainly uses advertisements in the magazine The Woman, read by women in military service even during the war. The study finds that although servicewomen were provided with skirts rather than trousers and several other 'feminine' clothing such as rayon knickers, boned corsets, and lisle stocking, the basic uniform of the women's services was similar in style to that of their male 'parent' forces. As the war continued, the work clothing of servicewomen became more 'masculine'. WRNS members, for instance, wore 'bell-bottoms'. However, as some servicewomen shortened their skirts to conform to a fashionable length, they tried to retain their femininity by adapting their uniform to their tastes. Many advertisements for the promotion of selling parts of uniform such as boned corset, and the encouragement of using hair salon, appeared in magazines. In them, for example, camp hairdressers introduced the hairstyle suitable for service caps. These advertisements probably helped women keep their femininity. As women in the same uniform were very proud of belonging to the war service, their ideal was a woman who balanced military duty with feminine beauty and maintained both ladylike quality and a sense of discipline.
\end{abstract}

Keywords: Uniform, WRNS, ATS, WAAC, Femininity

\section{Introduction}

\subsection{Purpose}

The purpose of this study is to explore how women in military uniforms maintained their femininity during the Second World War. The uniforms that women belonging to the Women's Royal Naval Service (WRNS), the Auxiliary Territorial Service (ATS), and the Women's Auxiliary Air Force (WAAC) wore are considered.

\subsection{Earlier Studies}

Previous research regarding the military uniform for women during the World War has been generally done in connection with femininity. For instance, Crosthwait, who researched the WAAC in the First World War, mentions that 'public fears were expressed about the effect of the army on women's femininity'. [1] Watson insists that 'the women's services were not welcomed with enthusiasm by the public' and that 'woman wearing military-style uniform' was thought to be unsuitable. [2] Concerning femininity in the Second World War, as Stone points out, sometimes women were not allowed to wear masculine trousers to keep their femininity during the war. [3] Kirkham states that the war did not masculinise or de-feminise women; instead, the Second World War strengthened their femininity. [4] Recently, Crang uses various government's papers on women's military uniform and provides us with important information of uniform restrictions by the government. [5] Therefore, it can be said that these previous researches have been done from outside 
and from above: what the public thought of women's military uniform, why the authority concerned did not allow women to wear trousers, whether the war strengthened or weakened women's femininity, and how the government tried to control their uniform.

\subsection{Material}

From a brief survey of these earlier studies, a few questions arise that would be addressed in this paper. It is necessary here to explore women's military uniform from within and from below as well as from outside and from above. How did women themselves think of their uniforms? What feelings and mentalities to their uniforms did they have? If the war actually masculinise women, how did women in military uniform resist this masculine tendency and retain their femininity even in the war?

This study bases its analysis on the following material and also takes these earlier studies into account. First, it uses advertisements that mainly appeared in the magazine named The Woman, published even during the war and read by approximately one million readers, including women in military services. The Woman placed many advertisements of beauty treatment, hair style and make-up for servicewomen to keep their femininity. Therefore, these advertisements are considered as most suitable to examine this study's purpose.

Second, this study considers surviving clothing, photographs, biographies and newspapers to approach women's feelings and mentalities in wartime. These records, including magazines mentioned above, have not been fully explored by earlier studies.

Third, official government documents should not be neglected. This study quotes these documents from Crang's book, because government documents he uses provide important information about uniform restrictions and control, and government's intention to promote military women's courage, royalty, and identity through their uniform. This study considers women's attitudes to their uniforms, by using both primary sources such as magazine advertisements and secondary sources such as Crang's book.

\section{Civilian Clothes and Military Uniform}

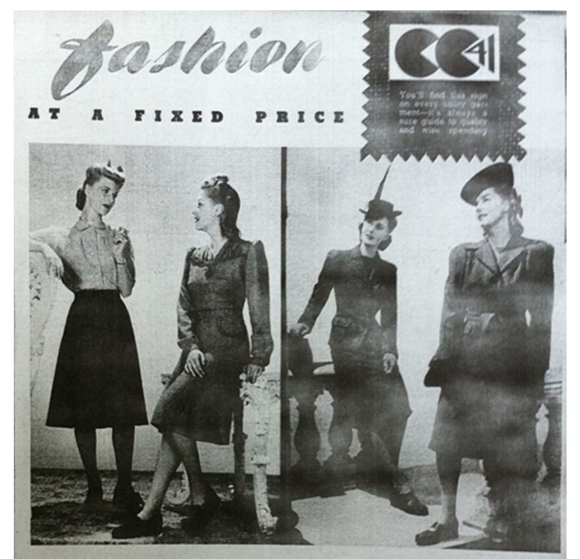

Figure 1. 'Fashion: CC41'.
As the Second World War continued, restrictions on clothing for civilian women increased. The restriction called 'CC41', for example, was one of the most distinguished during the war. ' $\mathrm{CC}$ ' of ' $\mathrm{CC} 41$ ' is the abbreviation for the Clothing Controls and '41' was added to it because these controls began in 1941. As the caption in Figure 1 says, this restricted clothing was also called 'utility garment', which was recommended as 'always a sure guide to quality and wise spending' for civilian women. [6]

In such a situation, the distance in style between the civvys (civilian clothes) and the military uniform began to shrink, partly because the simplicity and the femininity in dressing were considered to be important elements for the civvys.

Some of the civvys were inspired by the service clothing. For example, in an article 'You set the Styles today', the caption reads as follows: 'Look in the mirror, says Anne Edwards, and see who sets the fashions in this of war, 1943', and inspirations from the service clothes are indicated by three arrows, explaining respectively, 'War work made short hair popular', 'Your renovations inspire new designs', and 'civilian jackets copy service uniform' (Figure 2). Then, the caption calls attention and asks, 'Look at the long jacket--reaching down below the hip bone, fitted to the waist and lightly flared below with pockets on the hip. It is one of the most distinctive wartime fashions of today. Where does it come from?' [7] The author promptly replies that it comes 'from you girls who are in the service-it's the same sort of jacket that you wear in the ATS [Auxiliary Territorial Service] and WAAF [Women's Auxiliary Air Force]'.

As the caption that 'Twins in navy wool as smart for the Wren [Women's Royal Naval Service] as it is warm for her brother' in the article 'H.M.S. [His Majesty's Service] WAISTCOAT!' shows in Figure 3, this waistcoat was based on the WRNS [Women's Royal Naval Service] uniform. [8] In this way, some civilian clothing imitated the military uniform, and some parts of the military uniforms turned into those of civilian clothes.

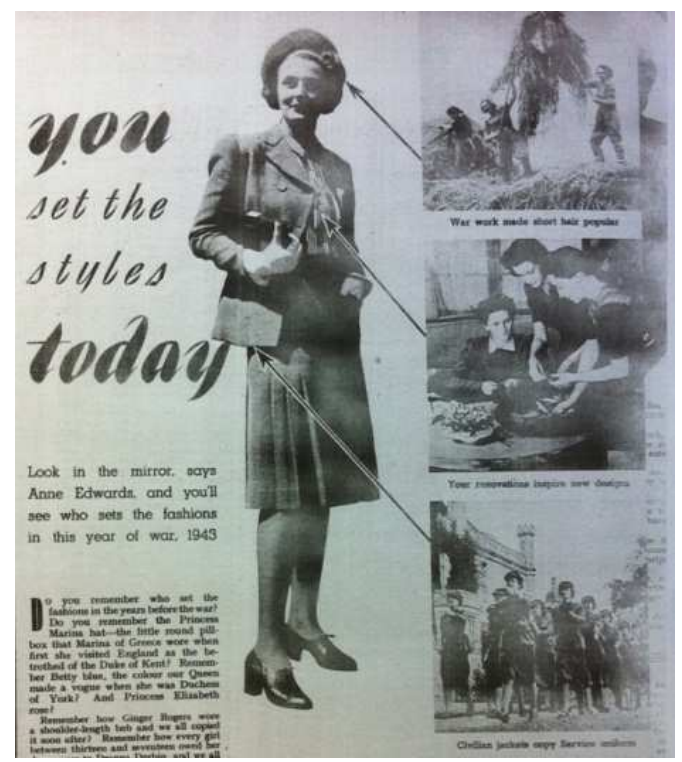

Figure 2. 'You set the Styles Today'. 


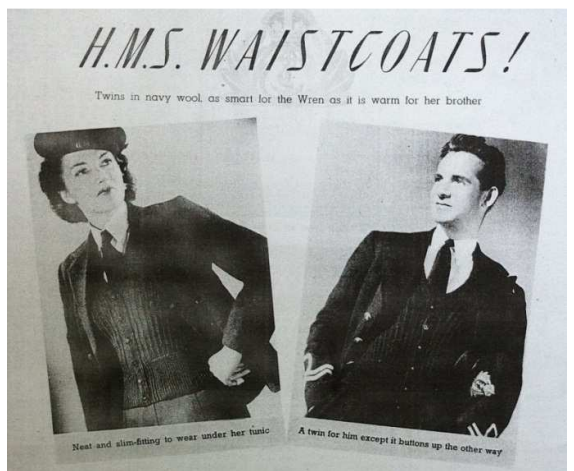

Figure 3. 'H.M.S. Waistcoat!'.

In the article, 'Smart exchanges', Anne Edwards shows her readers again that 'a service and a civilian girl could give each other tips on appearance' (Figure 4). [9] During the War, service and civilian girls gave each other hints and drew inspirations mutually. This partly means that military uniforms were very similar to civilian clothes and that military uniform was an icon of admiration for the civilian girls.

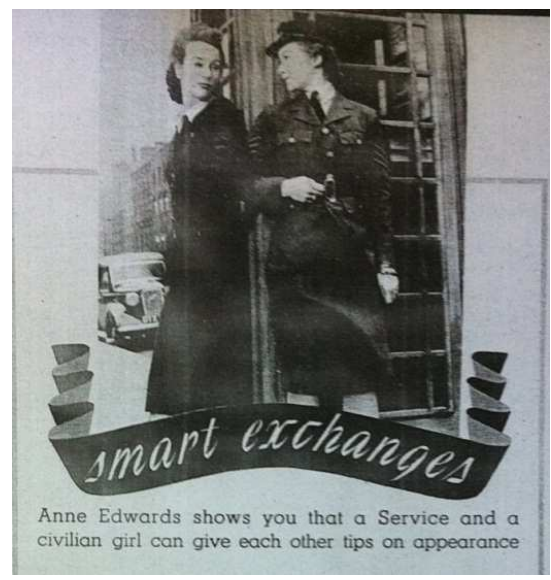

Figure 4. 'Smart Exchange'.

\section{Military Uniform}

\subsection{WRNS}

\subsubsection{Standard Uniform and Trousers}

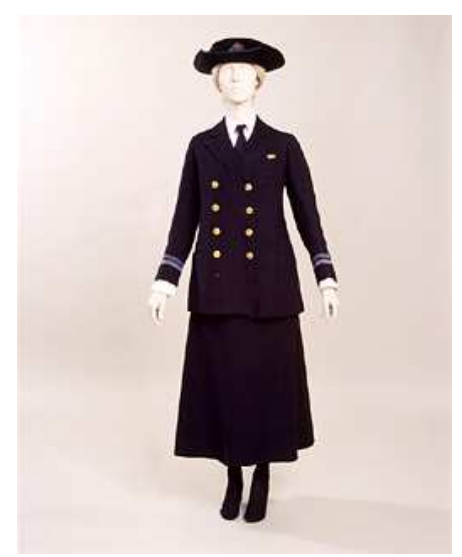

Figure 5. Uniform of the WRNS (1918).

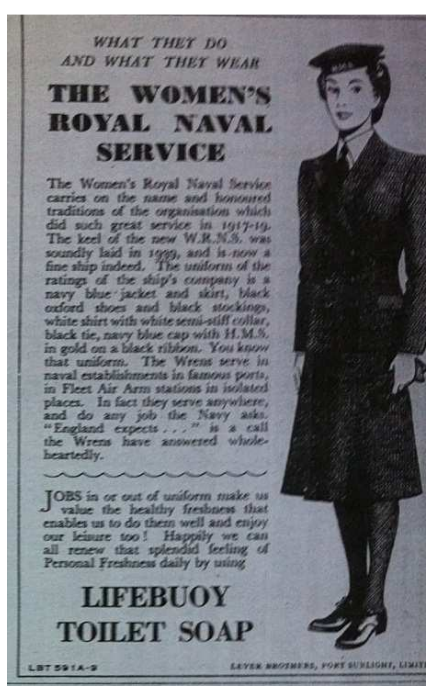

Figure 6. The WRENS (1939).

The WRNS uniform was the most popular of women's military uniforms. Figure 5 shows the uniform of the WRNS in 1918. The uniform for the Second World War changed in skirt length and hat shape. The length of the skirt's uniform was shortened, and the hat lost its brim and became smarter. The new WRNS uniform was seen in public for the first time at the National Service parade in Hyde Park in July 1939. One advertisement for the 'Lifebuoy Toilet Soap' in 1943 introduced the uniform for the Wrens [another abbreviation for Women's Royal Naval Service] (Figure 6).

The uniform of the ratings of the ship's company is a navy blue jacket and skirt, black oxford shoes and black stockings, white shirt with white semi-stiff collar, black tie, navy blue cap with H.M.S. in gold on a black ribbon. You know that uniform. [10]

Servicewomen were provided with skirts, not trousers and several other 'feminine' clothing such as rayon knickers, boned corsets, and lisle stockings. However, as the war continued, and the range of jobs expanded, the working clothing of servicewomen became more 'masculine'. [5] The WRNS had particular uniforms such as bell-bottoms, which were not seen in other services. As the article 'Wrens on abroad' on 29 June 1943 says, 'the five girls - officers and Wrens wore 'bell-bottomed' trousers and jerseys if it's cold'. [11] As Vonla McBride also mentions in her book, Never at Sea, 'An attractive, petite young Wren' wore 'navy blue trousers, neat jacket and jaunty little cap'. [12] The overall that had been introduced as a working-wear in the late 1930s [13] was another masculine clothing adopted by the WRNS.

Vonla McBride recalled that when she went to the WRNS, she had 'mountains of it [uniform]', because her belongings were 'two navy blue suits, a great-coat, a rain coat, shirts, collars, ties, thick black stockings and shoes more suited to parade work'. She further said 'I had always admired the Royal Navy and thought the WRNS uniform [had been] most becoming'. [12] She remembered that 'We were so pleased to get out of our overalls and into a neat uniform that we made no complaint about our lisle stockings and heavy brogue shoes, though nowadays, I am glad to say, fifteen denier 
nylons have replaced the stockings and a pair of smart black court shoes has been added to the quota of uniform'. [12]

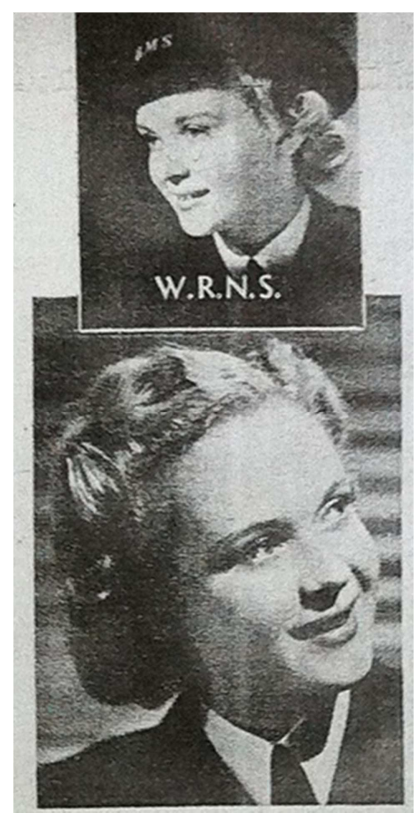

Figure 7. 'H.M.S.'

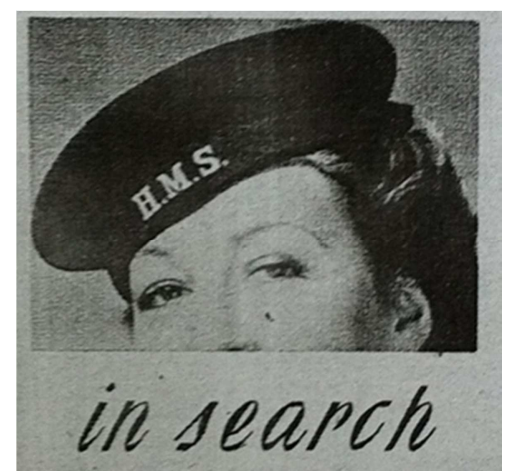

Figure 8. 'W.R.N.S.'

\subsubsection{Navy Blue Hat and Blue Bandanna}

Women liked the navy blue hat. For example, 'Anne (Figure 7) also loved hats, and she liked the sailor Wren hat. She was told that "the WRNS would welcome her and there were plenty of jobs for her to do...Anne liked the idea of the Wrens, liked herself in the sailor hat, so decided to discuss the matter with her husband'. [14] The passage reports that after the discussion, she determined to enter the service.

The article that appeared in Women on 29 November 1941 introduced the hairstyle suitable for this hat. 'The little round Wren hat sits so firmly and tightly on your head that there is no room for the curls on top that we used to wear' (Figure 8). [15]

Concern for such an attractive look seems to have invited a tragic accident. Jeremy A. Crang described this tragic minutely. [5] Ann Walker, who was working in radical drilling in a maintenance shed in 1944, was wearing a regulation blue bandanna distributed to WRNS machine operators as a protective head covering. However, as the fashion of the day, she had left a portion of hair showing at the front where the bandanna was tied in a bow. When she was leaning over her machine to change the size of the drill, some of her hair and bandanna got caught in the vertical driving shaft. After this horrific accident, she suffered 'a complete avulsion of 3/4' of the scalp. As a result of this tragedy, it was laid down the WRNS personal working on machines with moving parts would be issued with 'peaked safety caps' and that care was to be taken 'to ensure that no loose ends of hair are visible when the cap is worn'.

Though there were masculine clothes such as bell-bottoms and overall, and tragic accident, the standard uniform of the WRNS was generally regarded as the most stylish of the three women's services. [5, 16] According to Anne de Courcy, the blue-black design was chic, slimming and well-suited to youthful British complexions. [17] It was said that after the war, the British airline, British Overseas Airways Corporation, purchased surplus WRNS uniforms, not WAAF ones, for their stewardesses. [5, 18]

\subsection{ATS}

\subsubsection{Standard Uniform and Jerkin}

The Women's Army Auxiliary Corps (WAAC) played an active role in the First World War. On 31 March 1917, WAAC women wore their khaki uniforms when they landed in France. Military-style khaki jackets were worn not only by officers but also by some drivers, with the long skirts. The ranks wore pudding basin felt hats, and the officers wore man-style peaked caps. Figure 9 is a WAAC recruiting poster at the end of 1916. [19] Women in this poster put pudding basin felt hats on their heads. Figure 10 is the uniform for WAAC in 1917. The uniform was made of 'khaki wool gabardine suit with a beige silk shirt' and it was supplied by George B. Ashford Ltd of Birmingham, and the label "Woodrow, Piccadilly, London" was stuck on the khaki felt hat. [20] The WAAC was renamed the Queen Mary's Army Auxiliary Corps in May 1918, which ended up until 1919. The WAAC uniform was succeeded by that of the Army Auxiliary Corps (ATS), which was established in September 1938.

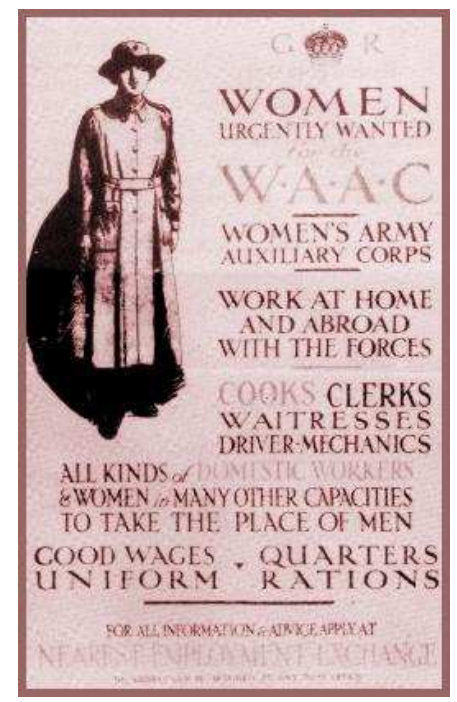

Figure 9. 'W.A.A.C. (1916)'. 


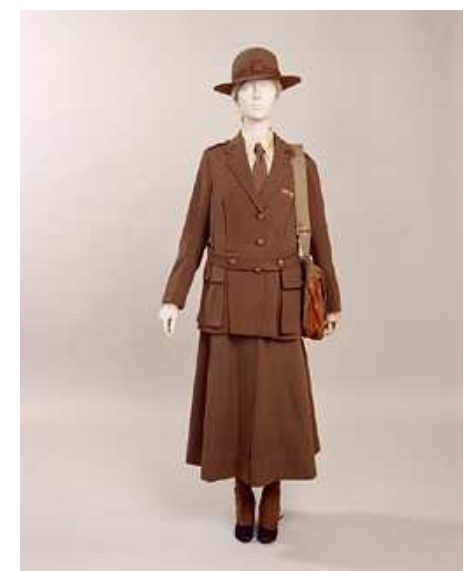

Figure 10. 'W.A.A.C. (1917)'.

Figure 11 is 'single-breasted, four-buttoned, sleeveless jerkin in soft brown leather with half-belt attached. Khaki cloth lining'. [21] The caption shows that 'this is an example of the first pattern ATS leather jerkin issued to Anti-Aircraft Gun site personnel from early 1941, Private E. F. Waldock served with the ATS attached to the Royal Artillery from 1942-1946. She saw service in the UK and in Northwest Europe'. With the continuity of the war and the expansion of the range of jobs, the ATS clothing also became 'masculine'. 'Jerkin', which ATS 'gunner' like Waldock put on at the gun sites was one of masculine battledresses.

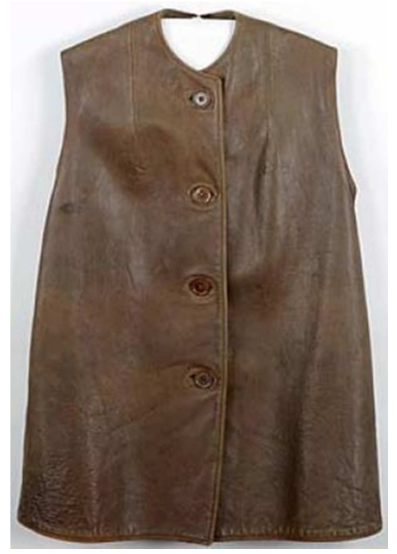

Figure 11. ATS Leather Jerkin.

\subsubsection{Khaki Colour}

As the article 'From "Civvies" to Khaki', indicates, [22] the khaki colour often meant the ATS uniform and it was the colour characteristic of the ATS. However, wearers sometimes disliked this drab khaki uniform. This caused a particular 'image' problem and the ATS service was often not an enticing prospect for a young woman. Oftentimes, the khaki colour did not suit the colouring of many women and the cut was shapeless and unfashionable. [5]

The War Office attempted to improve the 'profile' of the ATS. In the summer of 1941, the Director of the ATS was replaced by a much younger officer. This new DATS (Director of the ATS) sought to give the service more feminine appeal. The uniform was redesigned to make it smarter. This involved restyling the tunic so that it had a tighter waist and padded shoulders. [5]

Even in 1942, some girls who disliked 'khaki' sent their letters to The Woman. According to the article, 'Our views on ATS uniforms are that skirts and collars should be cream, not dusty khaki, but that the ties, which show every finger mark, should be dark brown'. [23]

According to an advertisement placed in The Woman on 29 March 1943, 'The Director [of the ATS] herself had a hand in the design of the smart, womanlike ATS uniform. It consists of a simply cut square-shouldered tunic and slim-fitting skirt. The unbelted great-coat fits snugly to the waist' [24] However, she did not mention the 'khaki' colour itself.

A number of other clothing such as rayon knickers, boned corsets, and lisle stocking that were provided for ATS women, were also unpopular among them. One recruit to the ATS, Winifred Lane, recounted that 'the famous khaki knickers, of silky-feeling rayon with elastic at the legs as the waist, were greeted with incredulous laughter'. Another was less amused by her new apparel. 'I'll never forget the loathing of seeing my leg clad in khaki lisle stocking', groaned Iris Bryce, 'I felt like my Gran'. She was placed on a charge of misappropriating the King's uniform after her first kit inspection. One of inspection officers who checked her kit and realised some items were missing, asked her, 'Where's the rest of it?' She lastly understood the officer's question and answered, 'Oh, you mean the bras and corsets, I couldn't wear those, especially the corsets, all those bones. No, I've got my own roll-ons. I've sent others to my Gran for her jumble sale'. There were many girls like her who substituted daintier briefs for their voluminous service knickers. [5]

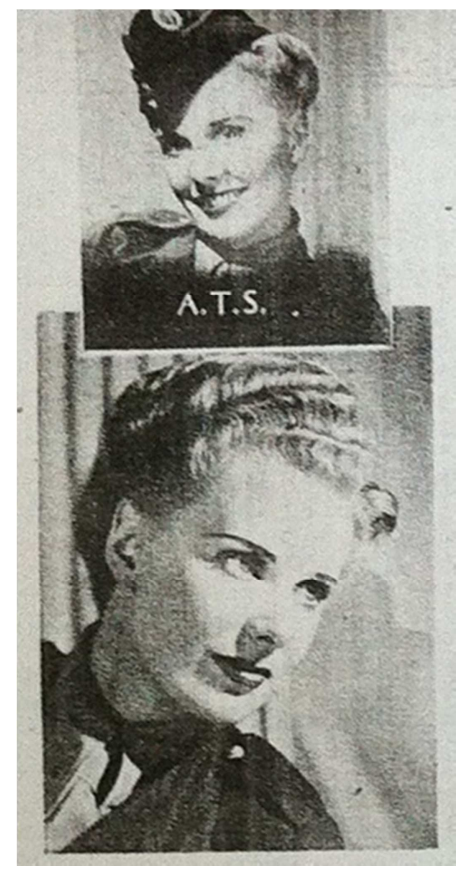

Figure 12. 'A.T.S.'.

\subsubsection{Hair Style Suitable for Caps, Corsets, and Make-up}

Service caps were one of the most popular of ATS uniform items. An article appeared in 1941 suggesting the hair style 
fit for this hat. The article says that 'This smart little cap is so small and neat itself that it demands a neat head to go with it'. [15] It continues to say that 'the perfect hair style to wear with your forage cap is a roll, curled up smoothly and firmly all round your head'. As seen in Figure 12, the neat hair style was recommended. After they enrolled in the service, two hats were given to them. 'Pat has two new hats. The trim peaked cap for duty-wear, and the perky walking-out cap which she is wearing in the photograph [Figure 13]'. [14] As women who wore hats appeared in the cover page in The Woman on 16 January 1943 (Figure 14), their hats attracted much attention. [25]

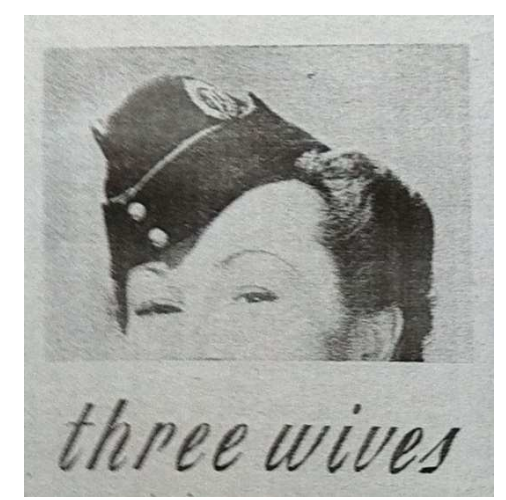

Figure 13. 'A.T.S.'.

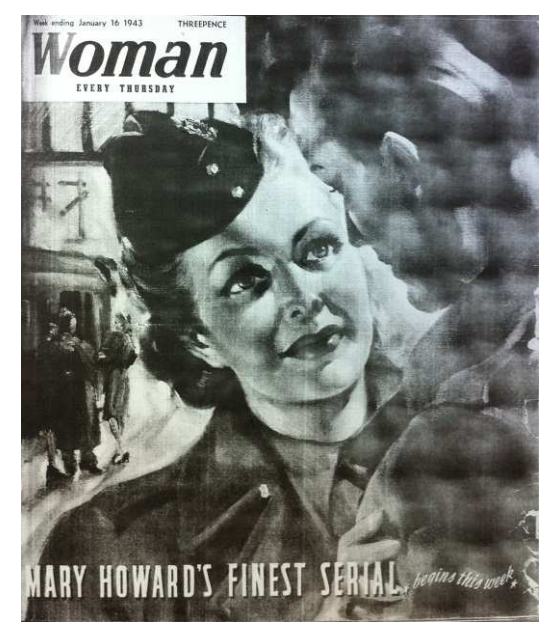

Figure 14. 'A.T.F. Woman in Cover Page'.

As soon as the military uniform was established, many advertisements for the promotion of using laundry and encouragement of selling weekly newspaper and commodities such as cocoa and toothpaste began to appear. ATS women in uniform who 'show frequently their splendid work', were utilised for these various advertisements. [26, 27, 28]

It was in the advertisement for the corset that women in military uniform were seen in The Woman for the first time. The advertisement for 'Spirella Corsetiere' says that 'in whatever branch of war service you are playing your part, Spirella will provide the figure support and control you will so assuredly need. Long hours of standing, hard work and vigorous exercise all call for the perfect figure support and control which Spirella alone can give'. (Figure 15) [29]
Spirella Corsetiere was a company that has specialised in made-to-measure corsets since it was established in 1904 at Oxford Circus, London. Two women in military uniform can be seen in the advertisement. The woman on the left side is from the ATS. The badge 'AT' is attached on her uniform. The woman on the right side is perhaps from the Auxiliary Fire Service (ATS).

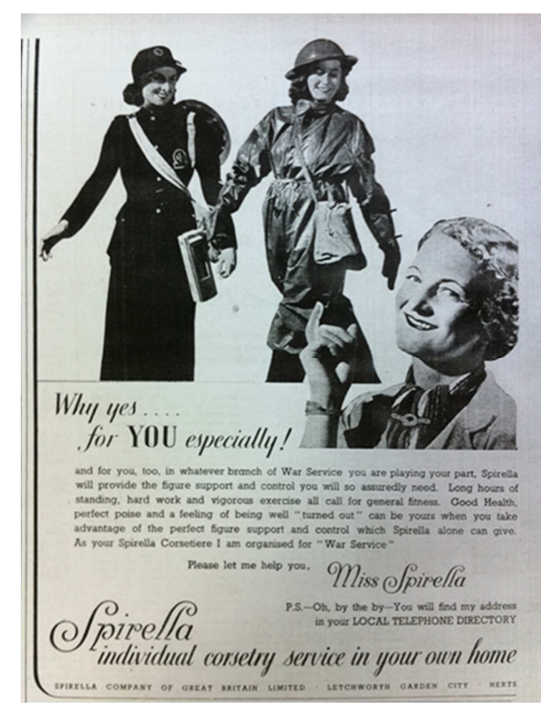

Figure 15. 'Why yes... for You especially!'.

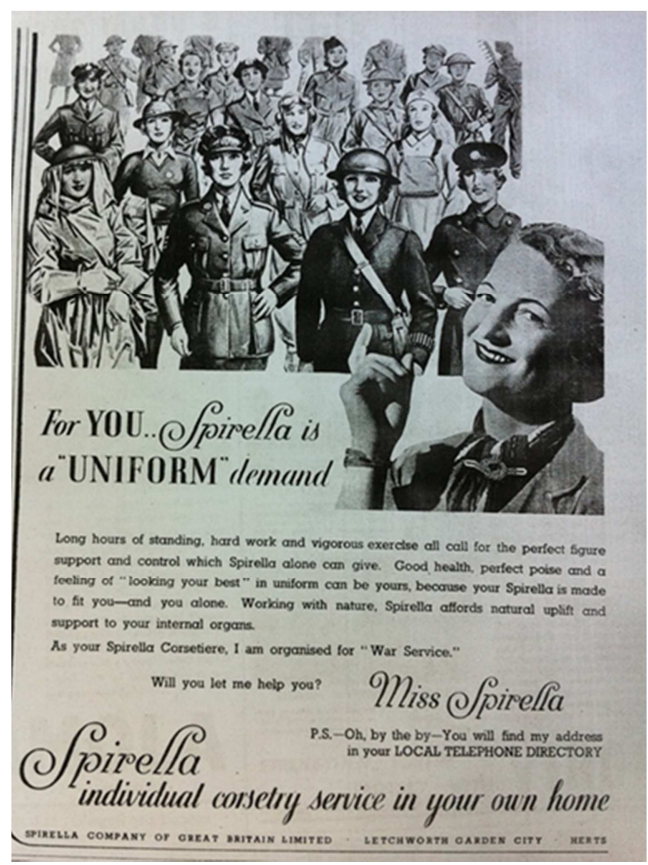

Figure 16. 'For you... Spirella is a "Uniform" demand'.

The next advertisement for Spirella appeared on 4 November 1939 (Figure 16). [30] The caption says again that 'Good health, perfect poise and a feeling of "looking your best" in uniform can be yours, because your Spirella is made to fit you---and you alone. Working with nature, Spinella affords natural uplift and support to your internal organs'. Women in military uniform entered here again. Besides ATS woman, WRNS woman, the WAAF, woman in the nurse 
uniform and other women can also be seen in the advertisement.

During the War, women were encouraged to wear the corset by the War Office. As Pat Kirkham mentions in her article, wearing corset helped women maintain 'feminine' shapes. [4] 'So many women' who 'have enrolled for service in the ATS, the WAAF, the AFS [Auxiliary Fire Service], and the WRNS', said the War Office, 'must be corseted and corseted correctly'. [31]

There was another war-time corset called 'pantee-girdle' and prepared for the women in service. The author of an article 'Wartime Corset' for Picture Post explained about it as follows:

For the AFS and ambulance girl, there is a special design. It's a pantee-girdle of elastic satin, with zip fastening, intended for wearing underslacks. It gives perfect freedom of movement and --- especially important for the ambulance driver--- supports against the danger of those spreading hips that may come from long hours of sitting. [31]

Even during the war, servicewomen in the ATS or in the AFS wore corsets, which, for a long time, were associated with femininity. Although as the case of Bryce mentioned above, corsets were disliked, as the author says, 'we are trying to combine feminine freedom [of movement] and feminine beauty'.

As mentioned above, khaki uniform and khaki colour were disliked by many women. However, there was suitable make-up for this khaki uniform. The explanation in an article says that 'khaki is a special problem', and 'needs a special make-up', and that khaki 'is apt to make you look sallow, so be sure to choose warm powders with rose overtones, and clear vermilion and flames for lipsticks'. [32] In an advertisement for 'Air Spun' powder, the woman having powder compact shows 'how to look younger in uniform'. (Figure 17) [33]

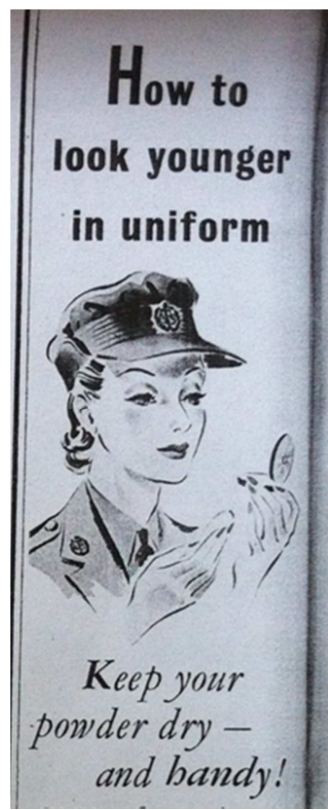

Figure 17. 'Air Spun'.
Regulations were enacted to govern women's appearance when in uniform. They included the stipulations that hair was to be neat, that make-up, if used, should be discreet and that nail varnish must not be 'highly coloured'. [34] Nonetheless, these regulations did not prevent women from trying to enhance their looks. [5] In an article of The Woman on 28 October 1939, Helen Temple told a woman reader that 'beauty is part of her equipment and she's ready for any marching orders, knowing that her loveliness will not desert her'. [32] As Pat Kirkham has commented, 'women in uniform took beauty and duty just as seriously as their civilian sisters'. [35]

Women made up by using face cream, face powder and lipstick in morning and night-time beauty rituals. The military authorities seemed willing to collaborate in these beauty endeavours. In the ATS, hairdressing salon was established at bases where there were large concentrations of servicewomen and a sleek khaki shoulder bag used as a receptacle for their cosmetics when off duty was issued. [5]

\subsection{WAAF}

\subsubsection{Standard Uniform and Dark Blue Slacks}

Edith Ridley Baker, in her book, pointed out about the introduction of the uniform for women air force, that 'the question of uniform naturally arose, and a number of high-ranking RAF [Royal Air Force] officers and Air Ministry officials were firmly convinced that the new service should have one of its own'. [36]

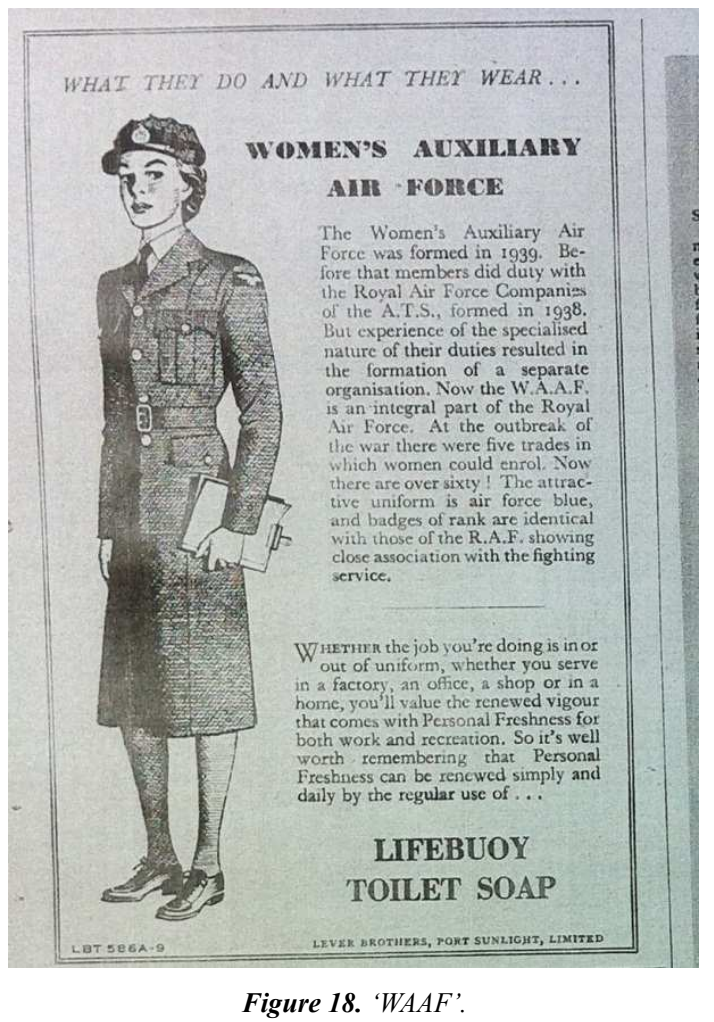

The uniform was first seen in public at the National Defence Rally in Hyde Park at the beginning of July 1939, salute in the March Past. [37] In an advertisement for the 
'Lifebuoy Toilet Soap', the uniform is described as below (Figure 18):

The Women's Auxiliary Air Force [WAAF] was formed in 1939 ... Now the W.A.A.F. is an integral part of the Royal Air Force... the attractive uniform is air force blue, and badges of rank are identical with those of the R.A.F. showing close association with the fighting service. [38]

Daisy Hills said that 'When I first joined in September 1939, I had no uniform', but 'After two or three weeks I was issued with a RAF blue-belted raincoat and beret with a metal RAF cap to pin on it. Also a navy armband with WAAF in red on it. A few lucky ones had grey lisle stockings and flat, black-laced shoes--- not always fitting'. [39]

An advertisement to recruit the WAAF was inserted in The Woman on 22 February 1941 (Figure 19). [40] There the woman wore the uniform that was inspired by that of the ATS, and also by that of the RAF airman's service. The WAAF uniform was based on the design of the RAF uniform. It was called 'the Royal Air Force blue uniform'. The colour called 'air force blue' was considered as characteristic of the WAAF. The jacket consisted of pleated breast pockets, large tunic skirt pockets and integral waist belt. [13]

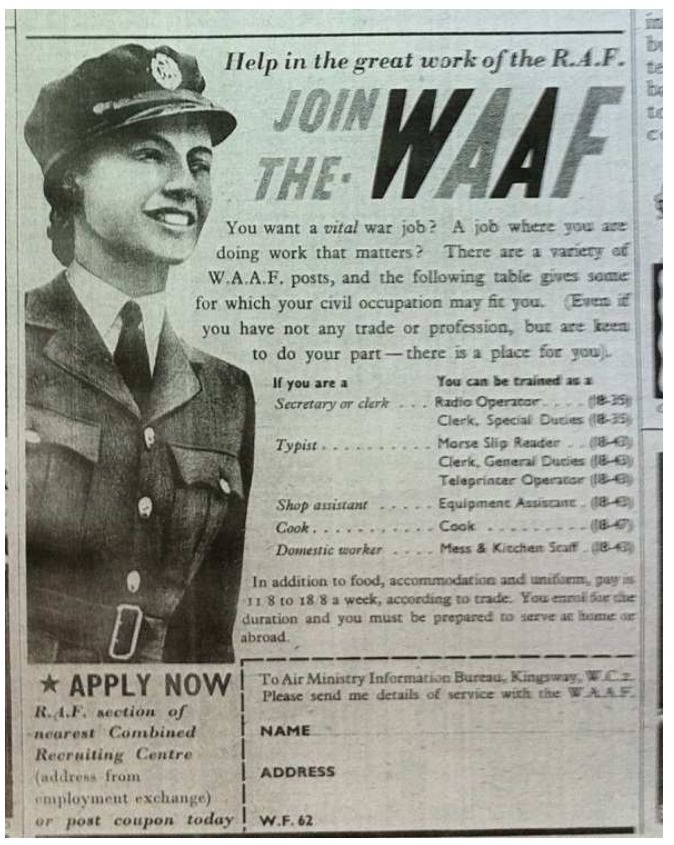

Figure 19. 'Join the WAAF'.

One article in 1941 says that after women enrolled in the service, a set of clothing will be supplied as below.

You will be given two uniforms (one straight away, the other after six months), great-coat, two pairs of shoes, three pairs of stockings, three shirts, six collars, one tie, two pairs of summer knickers and two pairs of winter weight, two vests, two brassieres and two suspender belts. [41]

As the war continued, the WAAF working clothing became 'masculine' and that of WRNS and ATS. There were long discussions over the issue of trousers for airwomen. In 1939, Jane Trefusis Forbes, Director of the WAAF, pressed for the provision of 'dark blue slacks' because 'women's lower limbs should be kept warm'. Yet some of her senior male colleagues resisted this assertion and said 'this form of not yet been universally accepted by women in this country'. Both came to a compromise that slacks would be made available as a temporary measure.

However, the air attacks on RAF stations during 1940 brought about a rethink. The raids meant that airwomen were often required to rush during the night from their sleeping quarters into protective trenches and spend long periods out in the cold. Forbes again called for 'slacks', which should be stocked at many bases and could be slipped into during an alert and provide the necessary warmth. However, this time the Treasury raised objections for reducing expenditure on these additional slacks. After a long debate, eventually, in 1941, official approval was given for an issue of 'blue slacks' to all airwomen, but the RAF authorities stated that these trousers were to be worn 'only when it is necessary to take shelter from air raids'. [5]

\subsubsection{Make-up, Hair Style for Caps, and Femininity}

The tendency of WAAF uniforms to become 'masculine' by adopting the trousers was not always strong. On the contrary, the femininity of dressing was often reinforced. For example, there was much make-up in the WAAF, which was considered to preserve femininity. Make-up was largely determined by their officers. However, women made up freely and chose suitable cosmetics for themselves, as one WAAF member says:

There's no real restriction on make-up once you get to your station... at least not at ours. It all depends on your WAAF officers and we have very nice ones. Make-up is about the only thing we can let ourselves go on and we all buy the very best makes. [42]

She used 'a very bright lipstick, regimental red of rose dawn and rose-coloured varnish - they both look grand with R.A.F. blue.' Meanwhile, there were some groups who had restriction rules about make-up and clothing, such that 'We are not to wear nail varnish, bright lipsticks or have our hair touching our collars. Remove cap like a man when entering building. Never remove tunic without special permission'. [43] The opinion that although make-up is at officer's own discretion, 'the authorities certainly want you to look as neat and attractive as possible' was heard repeatedly. [44]

Some of WAAF members had 'cold cream' and 'hand lotion', too. The Woman on 12 September 1942 placed a special article on how WAAF women make themselves up during their duty (Figure 20). One replier who 'worked as a driver and took care about her hands' says that 'Personally I put on lashing of cold cream at night, sleep in gloves, and rub in witch hazel ... when I can get it... to whiten the skin. I've got a very precious bottle of hand lotion, too, which I use before parties'. [42]

As Crang points out, the beauty process intensified to prepare for social events like parties. 'Like all girls', reported one WAAF, 'there's a tremendous pride in appearance. When we went to a dance last week, some girls spent the entire afternoon titivating themselves'. It was said by one airwoman 
that 'all told, more make-up is used in, than out of the WAAF'. [5] A wartime observer, Peggy Scott, considered this enhanced concern for appearance in the services 'a different femininity': 'It is not merely to attract men but because they think more of themselves. Doing men's work and being treated as mates by the men has given the girls a better sense of their own value'. [45]

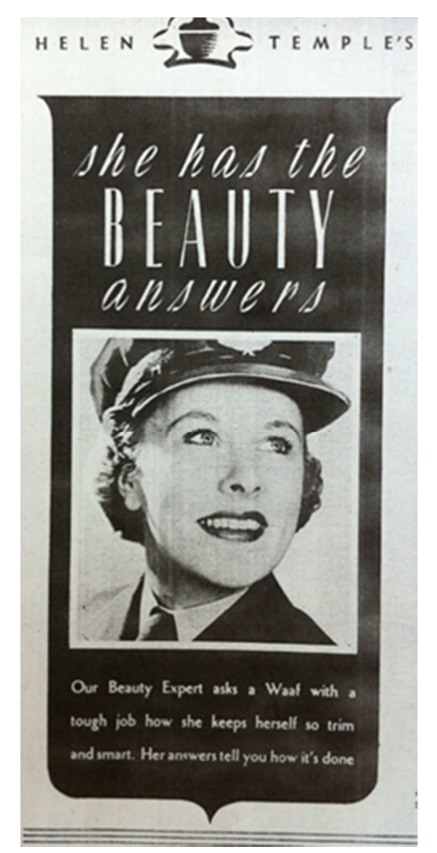

Figure 20. 'She has the beaty answers'.

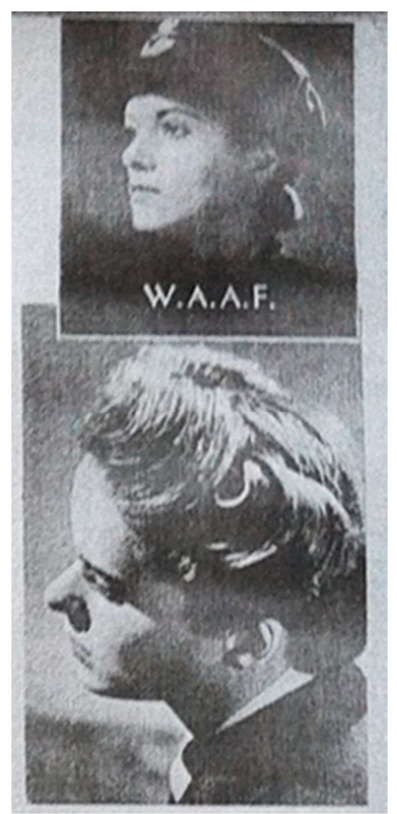

Figure 21. ' $W A A F$ '.

The WAAF cap took over its basic design from that of the ATS. In the opinions from readers of The Woman, one reader said she liked her uniform but not the hat. 'I am in the WAAF and find the uniform itself comfortable. But why are our hats so unsuitable? If we had forage caps like the ATS, the whole uniform would seem smarter-Miss M.R. (Nottingham)'. [23]
Another reader from Welling could not help accepting the WAAF cap 'far more ridiculous than any service cap', because 'this is for the War.... After all this is supposed to be a war for freedom, not a mannequin parade'. [24]

Women of the WAAF changed their hairstyle according to the cap. As an advertisement says, 'The WAAF cap with its soft pouched top does allow you to keep curls on top if you like, but the hair beneath your cap must be sleek and tidy' (Figure 21). [44] A woman of the WAAF mentioned that after she served in the military affair, she changed her hair. 'I found the best style for me was to roll my hair round a ribbon, into a halo... but some girls find this doesn't suit them so they curl their hair in curlers every night and wear a net on parade (which they soon take off!)'. As the WAAF had a camp hairdresser, the member went to her parlour 'Helen Temple's Beauty Parlour' once a week on Mondays. The caption says that 'A free cut and shampoo are now given to every Waaf... and set it obtainable for 6d extra'. [42]

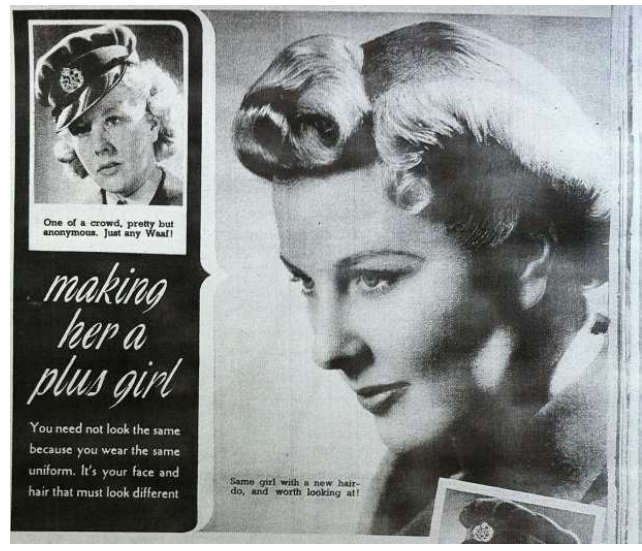

Figure 22. 'Making her a Plus Girl'.

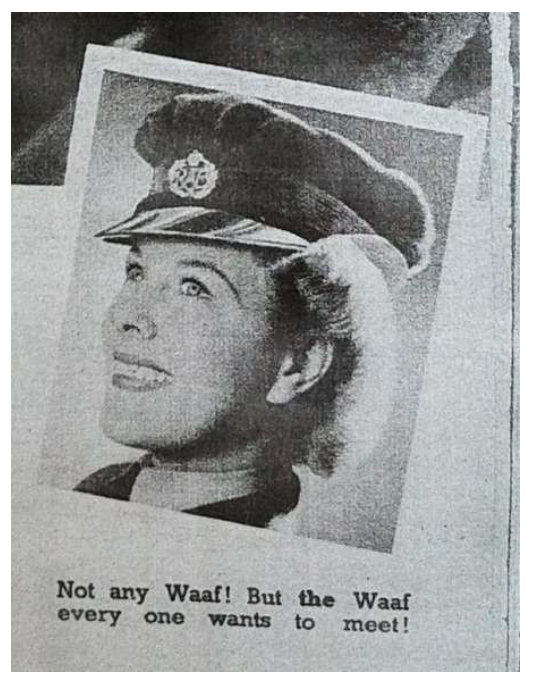

Figure 23. 'Not any Waaf!'.

The woman in the left side photograph above (Figure 22), first, shows a glum expression on her face and is described as 'one of a crowd, pretty but anonymous. Just any Waaf!' Then, in the next large photograph, she ties up her hair to fit the hat using new pins without cut hair. As a result, as the caption 
says, 'Same girl with a new hair-do, and worth looking at'. In another photograph below (Figure 23), in reversal, she is wearing her cap over tied hair and is smiling brilliantly, and the caption adds that 'Not any Waaf! But the Waaf everyone wants to meet!' [44]

Women in the service retained a sense of femininity by using make-up and changing the hairstyle. There were more women in their uniforms who kept their femininity by using other methods. Some women shortened their skirts so that they conformed to a fashionable length. Others padded their jackets' shoulders with government-issue sanitary towels to create a more alluring silhouette. There was a woman who splashed on lavish quantities of L'Heule Bleue perfume by Guerlain 'on the theory that the masculinity of WAAF uniform needed a little counteracting'. [5, 35, 46]

In this way, some women adapted their uniforms to their tastes. As Tessa has argued, this was partly to emphasise their individuality within the conformity of military life. [3] On this point, it is important to understand the caption attached to the advertisement for the hairstyle mentioned above (Figure 22) that 'You need not look the same because you wear the same uniform. It's your face and hair that must look different'. [44] Another WAAF case was coloured scarfs with which junior officers strolled around their necks. When pulled up by their seniors for infringing uniform regulations, they replied, 'oh, those rules don't apply to us, ma'am; you see, we are "operational!"' [5] 'On the surface we might all look the same', confided one WAAF officer, 'but underneath...ah, underneath... we were individual, female, and our souls were satin and lace'. [47] These adaptations of their uniforms were partly to emphasise their individuality and to retain their senses of femininity.

\section{After the War}

\subsection{Civilian Clothes}

After the Second World War ended, articles about the military uniform in magazines almost disappeared. [48] However, the military costume during the war affected the style of clothing even after the war. One article, "Once They were service Shirts!" says that "Veronica Scott shows you how a Woman Simplicity Pattern will transform your shirt into a dainty blouse'. Here women wear 'dainty blouses' which were transformed from 'service shirts'. Now women put on civilian clothes inspired by the military uniform and are projected as fashionable images (Figure 24). [49]

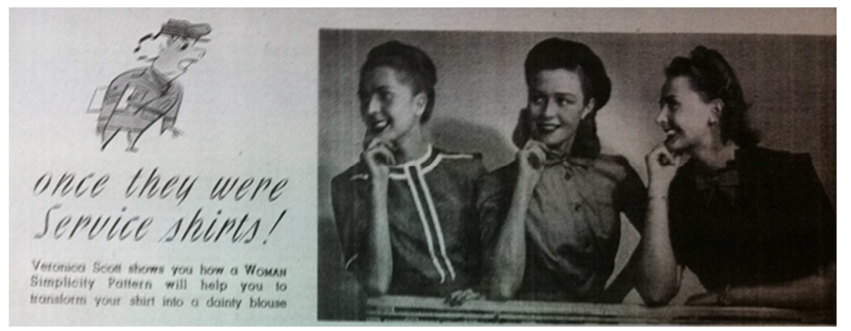

Figure 24. Once They were Service Shirts!

\subsection{New Uniform of the WRAF}

In 1952, Nancy Salmon, the Director of WRAF (Women's Royal Air Service), which was inaugurated in 1949, approached Victor Stiebel, a prominent couturier, to create a uniform 'specially for the feminine figure'. However, his design was opposed by several senior WRAF officers because it featured a stylish, shorter air force blue jacket with fewer square shoulders and a more accentuated waist, together with a flared skirt.

It was Anne Stephens, the inspector of the WRAF, who took particular offence. She protested that she was 'completely opposed for reason of both morale and practical value to a departure from the tradition of wearing the same uniform as a departure as the Royal Air Force'.

It is worthy of attention to her opinion about 'the degree of femininity' in strongly worded letter to Salmon. Stephens wrote to Salmon that

I understand that your desire to encourage the women of the service to both look and be feminine is your biggest reason for a new design of uniform...but are you really dissatisfied with the degree of femininity which prevails today? Surely our ideal for a member of the WRAF is a woman who always maintain her ladylike qualities coupled with a sense of discipline...I would claim that...we are in the happy position of having a vast majority of officers and airwomen who are both disciplined and ladylike, and that there is no need for a special crusade to feminise the service and therefore no need for a specially feminine cut of uniform'.

Then, Stephens mentioned the relationship between uniform and 'pride', 'morale' and 'loyalty'. 'In my experience, members of the WRAF are tremendously proud of belonging to the Royal Air Force. This is certainly the biggest morale factor in their service lives; the loyalty which members of the WRAF give to the WRAF is but secondary....The basic loyalty of the WRAF is the Royal Air Force and greatest pride is felt in wearing the same uniform as the Royal Air Force.... You know better than I the need for pride of service and esprit de corps to support the service man or woman in the day of trial and danger and in giving the WRAF a uniform different from the RAF I think we should strike a grave blow at the morale of the service'. [5]

Although for these reasons Stephens was strongly opposed to a departure from the traditional RAF design, the Air Council, which was asked to adjudicate on the matter, gave its consent to Stiebel's design. The new uniform was launched in 1954. [5, 50]

\section{Conclusion}

The basic uniform of the women's services was similar in style to that of their male 'parent' forces. Members of the WRNS wore a navy blue jacket, white shirt, black tie, and a navy blue sailor hat; their counterparts in the ATS wore a khaki jacket, shirt, and peaked cap; and those in the WAAF an air force blue jacket, pale blue shirt, black tie, and air force blue peaked cap. However, servicewomen were 
provided with skirts rather than trousers and several other 'feminine' clothing such as rayon knickers, boned corsets, and lisle stocking.

As the war continued, the range of jobs expanded, the work clothing of servicewomen became more 'masculine'. WRNS members wore 'bell-bottoms', ATS gunners put on battledress at their gun sites. As risks of raids at bases grew, WAAF flight mechanics donned 'dark blue slacks'.

Some servicewomen tried to retain their femininity by adapting their uniforms to their tastes. They shortened their skirts to conform to a fashionable length, used shoulder-pads to create an alluring silhouette, and substituted daintier briefs for voluminous service knickers.

As soon as the military uniform was established, many advertisements for the promotion of selling parts of uniform such as boned corset, and the encouragement of using hair salon, began to appear in magazines. Corset maker showed the clothing item to provide the figure support and control for servicewomen. Camp hairdressers introduced the hairstyle suitable for service caps. Cosmetic advertising for powder and lipstick makers utilised women in uniform effectively.

Some women entered military services only because they liked service caps and wanted to show themselves in uniform. However, as seen in many cases, women understood that their uniforms were created and worn for a war for freedom, not a mannequin parade.

Wearing the same uniform was the biggest morale factor in women's service lives. Women in uniform were tremendously proud of belonging to the war service. They knew the need for building up pride in and loyalty to a military uniform. Although the uniform of the women's services was similar in style to their male 'parent' forces, women did not give up keeping their femininity. Their ideal was a woman who balanced duty with beauty and maintained both ladylike quality and a sense of discipline.

\section{References}

[1] Elizabeth Crosthwait, "The Girl Behind the Man Behind the Gun: The Women's Army Auxiliary Corps, 1914-18', in L. Davidoff and B. Westover (eds.), Our Work, Our Lives, Our Words, Totowa, New Jersey: Barnes \& Noble Books, 1986, p. 163.

[2] Janet S. K. Watson, “Khaki Girls, VADs, and Tommy's Sisters: Gender and Class in First World War Britain," International History Review, XIX, 1 (February 1997), pp. 41-42.

[3] Tessa Stone, "Creating a (Gendered?) Military Identity: The Women's Auxiliary Air Force in Great Britain in the Second World War," Women's History Review, 8: 4 (1999), pp. 615-616.

[4] Pat Kirkham, "Fashioning the Feminine: Dress, Appearance and Femininity in Wartime Britain," in C. Gledhill and G. Swanson (eds.), Nationalising Femininity: Culture, Sexuality and British Cinema in the Second World War, Manchester: Manchester University Press, 1996, p. 155.

[5] Jeremy A. Crang, Sisters in Arms: Women in the British Armed Forces during the Second World War, Cambridge: Cambridge
University Press, 2020, p. 3, 32, 44-47, 112-115, 148-150, 230-233, 280.

[6] "Woman to Woman", The Woman (11th July, 1942), p. 3.

[7] "You set the Styles Today", The Woman, (31st July, 1941), p. 7.

[8] “Wrens Waistcoat!”, The Woman, (21st October, 1944), p. 20.

[9] "Smart Exchanges", The Woman (14th August., 1943), p. 6.

[10] 'The Women's Royal Naval Service," Advertisement, The Woman (11th September, 1943), p. 23.

[11] “Woman War Service Bureau: Wrens on board!", The Woman (29th July, 1943), p. 14.

[12] Vonla McBride, Never at Sea: Life in the WRNS, Reading: Educational Explorers Limited, 1966, p. 19, 25.

[13] Martin Brayley and Richard Ingram, eds., World War II: British Women's Uniforms, In Colour Photographs, London: The Crowood Press Ltd., 2007, p. 15.

[14] "Woman War Service Bureau," The Woman (7th November, 1942), p. 10.

[15] “Tuck These Under Your Cap," The Woman, (29th November, 1941), p. 7.

[16] J. Summers, Fashion on the Ration: Style in the Second World War, London: Profile Books, 2016, pp. 44-45.

[17] Anne De Courcy, Debs at War 1939-45: How Wartime Changed Their Lives, London: Weidenfeld and Nicolson, 2005, p. 205.

[18] C. Harris, Women at War in Uniform 1939-1945, Stroud: Sutton Publishing, 2003, p. 91.

[19] https://www.pinterest.jp/pin/44191640070709025/ [accessed: 29/MAY/2020].

[20] https://www.pinterest.jp/pin/456974693431918436/ [accessed: 29/MAY/2020].

[21] https://www.iwm.org.uk/collections/item/object/30092521 [accessed: 29/MAY/2020].

[22] "Woman's War Service Bureau: From Civvies to Khaki," The Woman (14th February, 1941), p. 11.

[23] "Woman to Woman," The Woman (8th August, 1942), p. 3.

[24] "What they do and what they wear: The Auxiliary Territorial Service," Advertisement, The Woman (29th March, 1943), p. 2.

[25] Front page, The Woman (16th January, 1943), p. 1.

[26] "HATS off to the A. T. S." Advertisement, The Woman (25th November, 1939), p. 44.

[27] "Where's my BOURNVILLE COCOA?" The Woman (28th May 1943), p. 2.

[28] "Solidox," The Woman (23th September, 1943), p. 24.

[29] "Why yes... for YOU especially!" Advertisement, The Woman (21st October, 1939), p. 3.

[30] "For YOU... Spirella is a 'UNIFORM' demand," Advertisement, The Woman (3rd November, 1939), p. 3.

[31] “War-Time Corset," Picture Post (2nd March, 1940), p. 26. 
[32] "Beauty Kit Bag," The Woman (28th October, 1939), p. 21.

[33] "How to Look Younger in Uniform," Advertisement, The Woman (24th Feburary, 1940), p. 34.

[34] Sandra Duncan, WW2 People's War, https://www.bbc.co.uk/blogs/internet/entries/f7126d19-2afa-3 231-9c4e-0f7198c468ab [accessed: 28/MARCH/2021].

[35] Pat Kirkham, 'Beauty and Duty: Keeping the (Home) Front', in P. Kirkham and D. Thoms, (eds.), War Culture: Social Change and Changing Experience in World War Two London: Lawrence and Wishart, 1995, pp. 24-25.

[36] Edith Ridley Baker, W. A. A. F. Adventure, London: Lonsdale, 1946, p. 7.

[37] Wadge D. Collette, Women in Uniform, London: Sampson Low, Marston, 1946, p. 172.

[38] "What they do and what they wear...: Women's Auxiliary Air Force," Advertisement, The Woman (3rd July, 1943), p. 16

[39] Beryl E. Escott, Women in Air Force Blue: The Story of Women in the Royal Air Force from 1918 to the Present Day, Wellingborough: Patrick Stephens, 1989, p. 100-101.

[40] “Join the WAAF," Advertisement, The Woman (22nd Feburary, 1941), p. 24.
[41] "Woman's War Service Bureau: The Girls Behind the Planes," The Woman (21st June, 1941), p. 9.

[42] "Helen Temple's Beauty Parlour: She has the Beauty Answers," The Woman (12th September, 1942), p. 15.

[43] "Women at War. No. 1: I'm a rookie in the WAAF," The Woman (September, 1942), p. 7.

[44] “Helen Temple's Beauty Parlour: Making her a Plus Girl," The Woman (19th October, 1942), p. 11.

[45] Peggy Scott, They Made Invasion Possible, London: Hutchinson, 1944, p. 70.

[46] Pat Kirkham, 'Keeping Up Home Front Morale: "Beauty and Duty" in Wartime Britain', in J. M. Atkins, (ed.), Wearing Propaganda: Textiles on the Home Front in Japan, Britain, and the United States, 1931-1945, New Haven, CT: Yale University Press, 2005, p. 216.

[47] M. G. Pushman, We All Wore Blue, London; Robson Books, 1944, p. 143.

[48] "Woman to Woman," The Woman (27th April, 1946), p. 3.

[49] "Once They were Service Shirts!" The Woman (12th January, 1946), p. 8.

[50] "New uniforms for WRAF," The Times (12 Feb. 1954). 